Review

\title{
Fermentation as an Alternative Process for the Development of Bioinsecticides
}

\author{
Alejandra B. Omarini ${ }^{1, * \mathbb{D}}$, Fernanda Achimón ${ }^{2}$, Vanessa D. Brito ${ }^{2}$ and Julio A. Zygadlo ${ }^{2}$ \\ 1 Instituto de Ciencias de la Tierra y Ambientales de La Pampa, CONICET, Universidad Nacional de La \\ Pampa, Mendoza 109, L6300DUG Santa Rosa, Argentina \\ 2 Instituto Multidisciplinario de Biología Vegetal, Facultad de Ciencias Exactas, Físicas y Naturales, \\ Universidad Nacional de Córdoba, CONICET, Av. Vélez Sarsfield 1611, Córdoba X5016GCA, Argentina; \\ fachimon@imbiv.unc.edu.ar (F.A.); vbrito@imbiv.unc.edu.ar (V.D.B.); jzygadlo@unc.edu.ar (J.A.Z.) \\ * Correspondence: aomarini@yahoo.com.ar
}

Received: 16 November 2020; Accepted: 5 December 2020; Published: 8 December 2020

\begin{abstract}
Currently, insect pest control is carried out through the application of synthetic insecticides which have been related to harmful effects on both human and environmental health, as well as to the development of resistant pest populations. In this context, the development of new and natural insecticides is necessary. Agricultural and forestry waste or by-products are very low-cost substrates that can be converted by microorganisms into useful value-added bioactive products through fermentation processes. In this review we discuss recent discoveries of compounds obtained from fermented substrates along with their insecticidal, antifeedant, and repellent activities. Fermentation products obtained from agricultural and forestry waste are described in detail. The fermentation of the pure secondary metabolite such as terpenes and phenols is also included.
\end{abstract}

Keywords: fermentation; agro-industrial waste; bioconversion; microorganisms; bioactive compounds; secondary metabolites; insecticidal properties; bioeconomy

\section{Introduction}

Agri-food and forestry industries produce large amounts of waste and by-products that contain significant amounts of sugars, proteins, lipids, minerals, and complex compounds. All these provide a great source of nutrients and physical support for microbial growth [1,2]. Fermentation is the most common biological conversion process of low-cost raw materials (plant-based) carried out by microorganisms. Through this process, microorganisms have the ability to recycle different types of plant-based materials and produce high-value compounds or useful products for different industries, while increasing the environmental and economic benefits associated with their disposal [3]. During fermentation, the macromolecules present in the substrate are broken down into smaller units due to the action of microbial extracellular hydrolytic enzymes. Furthermore, a variety of bioconversion pathways, such as oxidation, reduction, decarboxylation, glycosylation, methylation, acetylation, esterification, and ring cleavage, can occur, changing the compound structure and producing new metabolites and bioactive compounds [1,4].

Solid-state fermentation (SSF) is a biotechnological process in which microorganisms grow on the solid substrate in the absence, or near-absence of water but with enough moisture to support their growth [5]. On the contrary, submerged fermentation $(\mathrm{SmF})$ is usually carried out with either dissolved or suspended substrates, in an aqueous medium [6]. It is essential to choose the correct microorganisms, substrate/support, and bioreactor because they affect the economic viability of the process. A huge diversity of microorganisms such as filamentous fungi, basidiomycetes, bacteria, and different plant-based materials (substrates) have been used to carry out this process $[1-3,6,7]$. 
However, the SSF offers several advantages over SmF, including reducing production costs, lowering the generation of waste water, facilitating downstream processes, increasing product concentration, and lowering energy requirements [8]. In this context, SSF has emerged as a promising technology for the production of a broad variety of products such as enzymes, animal feed, mushrooms, single-cell protein, bioethanol, pigments, organic acids, biofertilizers, antibiotics, aroma compounds, and biopesticides from plant-based materials [3,9-16]. Therefore, the production and recovery of secondary metabolites through SSF or SmF of agro-industrial waste to achieve natural molecules with biopesticide properties becomes a beneficial alternative in terms of sustainability and economy if compared to their extraction from wild plants or their production by the chemical industry $[7,15]$.

Synthetic insecticides resulting from the petrochemical industry (e.g., carbamates, pyrethroids, and organophosphates) are the most commonly used method to control insect pests. However, their intensive and continuous application generates insect resistance, environmental pollution, and food contamination, affecting people's health. In dealing with this critical situation, fermentation of agricultural waste emerges as a new strategy for natural biopesticide production, while responding to the consumer's preferences for chemical-free products. Avermectin and spinosad, which are produced by Streptomyces avermitilis, and Saccharopolyspora spinosa, can be pointed out as the most successful insecticide products produced through solid fermentation and commercialized for the agricultural sector. Avermectin acts on the invertebrate-specific L-glutamate-gated chloride channels while spinosad acts on the nicotinic acetylcholine receptors and on the gamma-aminobutyric acid (GABA) receptors [17]. Okaramines are insecticides of fungal origin which also activate L-glutamate-gated chloride channels but they are not being marketed [18].

Currently, biopesticides represent a small portion of the pesticide market, however an annual growth rate of $15 \%$ is projected [19]. Biopesticides are effective in small amounts having high specificity to the target pests, and low risk to beneficial organisms (including honeybees) and a short half-life and, as readily biodegradable products, they do not pollute air or water [19]. Therefore, and considering the increase in the global market demand for natural products that meet consumer demands for health and well-being, it is clear that there is a promising future for the production of biopesticide compounds through fermentation using microorganisms, especially if we take into account the disadvantages of natural products obtained from plants-high extraction and purification costs and a low metabolites yield, commonly affected by environmental conditions. In this review we focus on the production and modification of secondary metabolites through the fermentation of agricultural waste. In addition, evidence of the insecticidal capacity of the natural products is provided.

\section{Fermentation Products-Insect Interaction}

To date there is limited literature on the relationship between metabolites produced during fermentation and their effects on insects. However, there is some evidence indicating that this relationship is based mainly on diet.

Many of the products obtained during fermentation are volatile compounds that act as insect attractants, pointing the way to a source of nutrients. Research was carried out in the forest area of Japan into the relationship between fermented tree sap and the insect community that is attracted to consume it [20]. The insect community is mainly characterized by Drosophila flies, and also by ants and sap beetles. [20]. The attraction of different insects to volatile compounds opened new possibilities for the development of traps using fermented products as baits for pest control. Drosophila suzukii, a fruit fly native from Southeast Asia and widely spread in America and Europe, generates great economic losses in the fruit sector because it affects ripe and healthy fruit. It has been demonstrated that its control can be carried out through traps using fermented fruit which is characterized by a significant acetic acid content. Drosophila females preferred to oviposit on diets rich in acetic acid compared to those lacking this product. This behavior prolonged the development time of the larvae and affected their performance [21,22]. The volatile compounds, isoamyl acetate and ethyl acetate, produced by Saccharomyces cerevisiae through fermentation have been demonstrated to attract Drosophila [23]. 
Likewise, the aromas generated by fermented fruit act as attractants of many adults of Lepidoptera and Hymenoptera [24]. For example, two butterfly species, Vanessa indica and Argyreus hyperbius, showed preference to consume fermented products such as rotting food rich in acetic acid and ethanol instead of monosaccharides [25]. The codling moth, Cydia pomonella, (Lepidoptera), a major pest of fruit trees, affects especially apple trees. This moth could be controlled by using traps containing fermented material produced by the yeasts Metschnikowia anaduensis and M. pulcherima, as they were attracted by the volatile compounds produced by them [24]. In addition, the volatile compounds ethyl acetate, ethyl hexanoate, phenyl ethanol, and other compounds produced by fermented fruits can act as sexual attraction pheromones for insect pests such as Agrochola helvola L. (Lepidoptera), Blaberus discoidalis Audinet-Serville (Dictyoptera), and Ceratitis capitata Wied (Diptera), becoming a potential tool for integrated pest management [24]. An example of this, is the use in traps of 3-methyl-1-butanol, 3-methylbutyl acetate, and ethyl hexanoate produced by fermented brown sugar which act as strong attractants for Vespula vulgaris (L), an insect pest present in New Zealand [26]. However, there are several actions needed like further research on product formulation, tests in field trials on research stations, and proper demonstration on commercial farms (8-20 ha) in order to introduce biopesticides into the market and to gain product adoption.

\section{Fermentation of Plant-Based Materials as Source of Biopesticide Compounds}

The diversification of natural compounds is an important factor for the development of new active metabolites. This can be achieved during the fermentation of plant-based materials (Table 1). As mentioned before, during this process the extracellular enzymes secreted by microorganisms are involved in the breakdown and/or transformation of complex substrates. This improves the properties of the new products and increases the yields of certain bioactive compounds [1]. At the same time, during fermentation a considerable amount of secondary metabolites are produced. These compounds are synthesized and excreted at the end of the exponential phase of microbial growth or trophophase, but mainly during the stationary phase or idiophase. These compounds do not play any important role in microbial growth or maintenance of the cellular functions [27]. For example, the fermentation of Parkia biglobosa (African locust bean) produced metabolites that acted as insecticides against Callosobruchus maculatus [28]. Likewise, the extract obtained after the fermentation of neem leaves and wild garlic mixture was the most effective formulation in reducing the population density of whitefly (Bemisia tabaci) and aphids (Myzus persicae) of tomato crops [29]. The fermentation of eucalyptus leaves, waste from the forestry industry, by edible mushrooms resulted in the biotransformation of 1,8-cineole, the main terpene of the essential oil, to 1,3,3-trimethyl-2-oxabicyclo [2.2.2] octan-6-ol and 1,3,3-trimethyl-2-oxabicyclo [2.2.2] octan-6-one [14], which showed different pesticide activities [30,31].

Citrus peel waste (CPW) represents $50 \%$ of the citrus biomass generated by the citrus processing industry and is an important source of bioactive compounds such as flavonoids. Flavanones and polymethoxylated flavones are characteristic flavonoids found in citrus peels. Fermentation of the glycosylated flavanones, hesperidin and naringin, by Aspergillus saitoi generated 8-hydroxyhesperetin, 6-hydroxynaringenin (carthamidin) and 8-hydroxynaringenin (isocarthamidin), with improved bioactivities [32]. Other products synthesized through fermentation of citrus peels were identified, such as aglycones eriodictyol, hesperetin, and naringenin [32]. Naringenin showed a mortality of $22.5 \%$ on Spodoptera litura larvae after its ingestion [33]. Ellagic acid can be obtained through SmF of orange peel waste with Aspergillus fumigatus [34]. When female Drosophila melanogaster were fed with a diet containing ellagic acid $(200 \mu \mathrm{M})$ there was a decrease in oviposition [35]. The SSF of lemon, orange, grapefruit, and tangerine waste carried out with Fusarium oxysporum, Penicillium purpurogenu, Trichoderma harzianum, and Aspergillus niger, produced chlorogenic acid, didymin, apigenin 7-O-apiosyl-glucoside, pinoresinol, medioresinol, naringin, and hesperidin [36]. Chlorogenic acid caused a mortality of $32.5 \%$ when consumed by S. litura larvae [33]. In addition, chlorogenic acid inhibited $\alpha$-glucosidase, an enzyme that hydrolyzes polysaccharides to monosaccharides, thus affecting the nutrition capabilities of S. litura [37]. The insecticidal effect of naringin and hesperidin could 
be due to their inhibitory activity against the enzyme acetylcholinesterase (AChE) [38]. Recently, hesperidin was used for the development of a novel insecticide with lower environmental impact, the metal-insecticide magnesium-hesperidin complex [39].

SSF of Morus alba leaves with the edible fungi Monascus anka increased the production of flavonoids, quercetin, and kaempferol [40]. The production of kaempferol, as well as two kaempferol $\mathrm{O}$-diglycosides, through fermentation of green lentils by the fungus Epicoccum nigrum was also reported [41]. The plant Alnus sieboldiana is widely distributed in warm regions of the Northern Hemisphere and is usually infected by Penicillium spp., which induces changes in the plant volatile profile. The fermentation of $A$. sieboldiana male flowers by Penicillium spp. caused changes in the compounds profile. The contents of naringenin and pinocembrin were reduced after a 6-month fermentation while new compounds such as kaempferol, quercetin, pinocembrin dimethyl ether, 5,7-dimethoxy-3-hydroxyflavanone, and 5,7-dimethoxy-3-hydroxyflavone were produced through bioconversion. Authors suggested that the hydroxylation of naringenin at positions C-3 and C- $3^{\prime}$ produced kaempferol and quercetin, respectively, while methylation, hydroxylation, and oxidation of pinocembrin gave three 5,7-dimethoxyflavonoids [42]. Pei et al. [43] reported production of kaempferol and astragalin through fermentation. Both quercetin and kaempferol showed high mortality rates against $S$. litura larvae $[33,44]$. In addition, quercetin inhibited the oviposition of the melon fly Bactrocera cucurbitae [44].

Glycosylation of flavonoids is an effective strategy to improve solubility and bioavailability, important to reach specific target sites and for the stability of products towards enzymatic degradations [45]. The $\beta$-glucosidase is responsible for the bioconversion of $\beta$-glucoside isoflavones into isoflavone aglycones [46]. Although flavonoid aglycones typically exhibit better biological activity in cell assays than their glycosides, the use of the aglycones is limited because of their low water solubility and rapid metabolism in vivo [47]. The fermentation of flavonoids by Isaria fumosorosea ACCC37814 produced glycosylation of the free aromatic hydroxyl group at the B rings of flavonoids [47]. Quercetin 3-O- $\beta$-D-glucoside exhibited the highest antifeedant and contact toxicity activities against Sitophilus zeamais and Prostephanus truncatus, insect pests associated with stored maize. The insecticidal activities of the flavonoids are probably due to the presence of a keto group at $C-4$ position, or a hydroxyl group at C-5 and C-7 positions [48]. The results of Aboshi et al. [49] showed that flavonoid glycosides were more toxic against Spodoptera litura larvae than monoglycosides. Glycosylation of flavonoids also happened in Escherichia coli [50,51].

Lactic acid bacteria can disintegrate vegetal cell walls, increasing the release of phenolic compounds from lignin or condensed tannins [52]. Lactobacillus plantarum can fully degrade gallotannins through the action of tannase or tannin acyl hydrolase (EC 3.1.1.20), which catalyzes hydrolysis of ester bonds, yielding glucose and gallic acid as products. Gallic acid is subsequently decarboxylated to pyrogallol. The addition of pyrogallol (125 ppm) to the diet affected the emergence of $S$. litura adults by $60 \%$, while larval mortality reached 56\% [53]. The application of gallic acid (5 ppm) reduced the oviposition and ovipunctures of Bactrocera cucurbitae by $50 \%$ [44]. A decrease in oviposition of Trogoderma granarium females fed with a diet containing gallic acid was also reported. This could be related to follicular cell necrosis and to disorganization and degeneration of oocytes among others [54]. Different fermentation processes (SmF or SSF) were implemented for the production of high concentrations of gallic acid using several natural tannin-rich substrates (eucalyptus leaves, pomegranate peel, banana peel, and wheat bran) [55].

Hydroxycinnamic acids are rare to find in free form and are present in plant tissues, mainly, as glycoside esters. Solid-state fermentation of rice bran with a single or mixed culture of Aspergillus oryzae and Rhizopus oryzae, produced different phenolic acids, such as ferulic acid, 4-hydroxybenzoic acid, caffeic acid, sinapic acid, vanillic acid, and syringic acid [56]. Phenolic acids such as $p$-coumaric acid, ferulic acid, and dihydrocaffeic acid sprayed individually or in mixtures, on different plants can reduce the reproductive period or fertility of the insect pests Sitobion avenae and Sesamia nonagrioides [57]. Caffeic acid represents from $75 \%$ to $100 \%$ of the total hydroxycinnamic acids found in fruits, while ferulic 
acid is the most predominant phenolic acid of cereal grains [52]. The esters of hydroxycinnamic acids are converted into acids during the fermentation process. These acids are then decarboxylated to generate vinyl phenol, vinyl guaiacol, and vinyl catechol through the phenolic acid decarboxylase. Their further reduction generated ethyl phenol, ethyl guaiacol, and ethyl catechol [52] that showed insecticidal activity against mosquitoes, flies, and aphids [58-60]. Ethyl phenol and ethyl guaiacol had a lethal dose LD90 of 134 and $455 \mu \mathrm{g} /$ larvae, respectively, on the 4th instar larvae of Spodoptera littoralis, while their antifeedant property was $100 \%$ with $250 \mu \mathrm{g} / \mathrm{cm}^{2}$ in both compounds [61]. Fermentation of kiwi pulp by L. plantarum promoted changes in the phenolic profile. The main phenolic acids present in the fermented material were protocatechuic and chlorogenic acids (dihydroxy coumarin and $p$-coumaric acid). On the contrary, catechins, epicatechins, and gallic acid are degraded by $L$. plantarum during fermentation, triggering an increase in the scavenging activity and improving the antioxidant capacity of the fermented pulp, if compared to the non-fermented one. [62]. The phenolic compounds $p$-coumaric acid and protocatechuic acid showed insecticidal activity against S. zeamais, probably through the inhibition of AChE activity [63]. During fermentation, lactic acid bacteria convert caffeic acid into dihydrocaffeic acid due to the action of the phenolic acid reductase. This compound showed antifeedant and cytotoxic activity against $S$. littoralis sixth instar larvae [64]. Other volatile compounds, such as trans-2-hexen-1-ol, 1-octanol, citronellol, geraniol, (E)-2-hexenal and methylheptenone can also appear during lactic acid bacterial fermentation [65]. The volatile alcohol, trans-2-hexen-1-ol, improved the activity of the aggregation pheromone of Anthonomus grandis (Coleoptera), which allowed the development of traps for capturing insects [66]. Furthermore, trans-2-hexen-1-ol and (E)-2-hexenal showed insecticidal effect against S. zeamais [67,68].

Fermentation can also generate new products whose bioactivities have not yet been determined. For example, fermentation of Stevia rebaudiana by Saccharomyces cerevisiae produced three new terpenoids, sterebins O, P1, and P2 with melanogenesis-inhibiting properties [69]. Dong et al. [70] reported the fermentation of Illigera aromatica by the fungus Clonostachys rogersoniana and two new monoterpenoids, $\left(1 R^{*}, 3 R^{*}, 4 S^{*}, 6 R^{*}\right)$-6,8-dihydroxymenthol and cis-4-hydroxy-5-(1-hydroxy-1methylethyl)-2-methyl-2-cyclohexene-1-one, were obtained. Seven new diterpenoids named as heptemerons $\mathrm{A}-\mathrm{G}$ were obtained through the fermentation by the basidiomycete fungus Coprinus heptemerus [71].

However, the acceptance of natural products as insecticides for pest management in crops faces certain difficulties related to the identification of the active metabolites and their modes of action, the short shelf life of the compounds, and the lack of global regulatory harmonization, among other factors [19].

Table 1. Bioactive products obtained through fermentation of agro-industrial wastes or by-products by different microorganisms.

\begin{tabular}{|c|c|c|c|}
\hline Fermented Substrate(s) & Microorganism & Product(s) & Reference \\
\hline $\begin{array}{l}\text { Eucalyptus leaves and } \\
\text { 1,8-cineole }\end{array}$ & $\begin{array}{l}\text { Pleurotus ostreatus } \\
\text { Favolus tenuiculus }\end{array}$ & $\begin{array}{l}\text { 1,3,3-trimethyl-2-oxabicyclo [2.2.2] } \\
\text { octan-6-ol, and } \\
\text { 1,3,3- trimethyl-2-oxabicyclo [2.2.2] } \\
\text { octan-6-one }\end{array}$ & [14] \\
\hline 1,8-cineole & $\begin{array}{c}\text { Mucor ramannianus } \\
\text { Aspergillus niger }\end{array}$ & $\begin{array}{l}\text { 1,3,3-trimethyl-2-oxabicyclo [2.2.2] } \\
\text { octan-6-ol, and } \\
\text { 1,3,3- trimethyl-2-oxabicyclo [2.2.2] } \\
\text { octan-6-one }\end{array}$ & [31] \\
\hline $\begin{array}{l}\text { Lime peel (hesperidin } \\
\text { and naringin) }\end{array}$ & Aspergillus saitoi & $\begin{array}{l}\text { 8-hydroxyhesperetin, } \\
\text { 6-hydroxynaringenin, } \\
\text { 8-hydroxynaringenin, eriodictyol, } \\
\text { hesperetin, and naringenin }\end{array}$ & [32] \\
\hline
\end{tabular}


Table 1. Cont.

\begin{tabular}{|c|c|c|c|}
\hline Fermented Substrate(s) & Microorganism & Product(s) & Reference \\
\hline $\begin{array}{l}\text { Orange peel } \\
\text { (polyphenols) }\end{array}$ & Aspergillus fumigatus & Ellagic acid & [34] \\
\hline $\begin{array}{l}\text { Lemon, orange, } \\
\text { grapefruit, } \\
\text { and tangerine peels }\end{array}$ & $\begin{array}{c}\text { Fusarium oxysporum } \\
\text { Penicillium purpurogenu } \\
\text { Trichoderma harzianum } \\
\text { A. niger }\end{array}$ & $\begin{array}{l}\text { Chlorogenic acid, didymin, apigenin } \\
\text { 7-O-apiosyl-glucoside, pinoresinol, } \\
\text { medioresinol, naringin, } \\
\text { and hesperidin }\end{array}$ & [36] \\
\hline Morus alba leaves & Monascus anka & Quercetin and kaempferol & [40] \\
\hline Green lentils & Epicoccum nigrum & $\begin{array}{c}\text { Kaempferol and } \\
\text { kaempferol } O \text {-diglycosides }\end{array}$ & [41] \\
\hline $\begin{array}{c}\text { Alnus sieboldiana } \\
\text { male flowers }\end{array}$ & Penicillium spp. & $\begin{array}{c}\text { Kaempferol, quercetin, pinocembrin } \\
\text { dimethyl ether, } \\
\text { 5,7-dimethoxy-3-hydroxyflavanone, } \\
\text { and 5,7-dimethoxy-3-hydroxyflavone. }\end{array}$ & [42] \\
\hline Naringenin & Escherichia coli & Kaempferol and astragalin & [43] \\
\hline $\begin{array}{l}\text { Flavonoids (naringenin, } \\
\text { hesperetin, luteolin, } \\
\text { diosmetin, apigenin, } \\
\text { genistein, formononetin, } \\
\text { and kaempferol) }\end{array}$ & Isaria fumosorosea & $\begin{array}{l}\text { Mono-methylglucosides, } \\
\text { mono-glucoside, } \\
\text { and di-methylglucoside }\end{array}$ & [47] \\
\hline Tannins and gallotannins & Lactobacillus plantarum & Glucose, gallic acid, and pyrogallol & [52] \\
\hline $\begin{array}{c}\text { Tannin-rich substrates } \\
\text { (eucalyptus leaves, } \\
\text { pomegranate peel, } \\
\text { banana peel, } \\
\text { guava leaves, and } \\
\text { wheat bran) }\end{array}$ & $\begin{array}{c}\text { A. niger } \\
\text { Trichoderma viride }\end{array}$ & Gallic acid & [55] \\
\hline Rice bran & $\begin{array}{l}\text { Aspergillus oryzae } \\
\text { Rhizopus oryzae }\end{array}$ & $\begin{array}{c}\text { Ferulic acid, 4-hydroxybenzoic acid, } \\
\text { caffeic acid, sinapic acid, vanillic acid, } \\
\text { and syringic acid }\end{array}$ & [56] \\
\hline Kiwi pulp & L. plantarum & $\begin{array}{l}\text { Protocatechuic chlorogenic acids } \\
\text { (dihydroxy coumarin } \\
\text { and } p \text {-coumaric acid) }\end{array}$ & [62] \\
\hline Apple juice & $\begin{array}{l}\text { Lactic acid bacteria } \\
\text { (Lactobacillus spp. and } \\
\text { Bifidobacterium spp.) }\end{array}$ & $\begin{array}{l}\text { Trans-2-hexen-1-ol, 1-octanol, } \\
\text { citronellol, geraniol, }(E)-2 \text {-hexenal, } \\
\text { and methylheptenone }\end{array}$ & [65] \\
\hline Stevia rebaudiana & Saccharomyces cerevisiae & Sterebins $\mathrm{O}, \mathrm{P} 1$, and P2 (terpenoids) & [69] \\
\hline Illigera aromatica & $\begin{array}{l}\text { Clonostachys } \\
\text { rogersoniana }\end{array}$ & $\begin{array}{c}\left(1 R^{*}, 3 R^{*}, 4 S^{*}, 6 R^{*}\right)-6,8 \text {-dihydroxymenthol, } \\
\text { and cis-4-hydroxy-5-(1-hydroxy-1- } \\
\text { methylethyl)-2-methyl-2- } \\
\text { cyclohexene-1-one (terpenoids) }\end{array}$ & [70] \\
\hline
\end{tabular}

\section{Fermentation of Pure Secondary Metabolites}

Biological catalysts make production of complex chemicals and by-products easier and cheaper than using purified enzymes. They enhance specificity to reactions and eliminate complicated separation and purification steps. Furthermore, the capability of biological agents to produce valuable products under moderate conditions makes them attractive and powerful tools [72]. Microorganisms can catalyze reactions that allow structural modifications of low-cost natural compounds such as terpenes or phenols. Therefore, it is possible to obtain valuable products with regio- and stereo-selective reactions. 


\subsection{Terpenes}

Terpenes are the most common type of chemical compound found in plant essential oils. They are cyclic hydrocarbons made up of isoprene units $\left(\mathrm{C}_{5} \mathrm{H}_{8} \mathrm{n}\right.$; the $\mathrm{n}$ indicates the number of units involved). Essential oils and/or their pure terpenes have been included in insecticidal formulations due to their low toxicity and high volatility. Currently there are considerable amounts of plant-based crop protection products commercially available [73,74]. The composition of essential oil-based pesticides, as well as the amount of the active metabolites, are guaranteed by the International Standardization Organization (ISO).

The main difficulty in the fermentation of terpenes is due to the fact that these types of compounds have strong antimicrobial activity. Hence, it has become very important to carry out the selection of biotransformation agents (either microorganisms or their enzymes), substrates (e.g., essential oils), and conditions so as to obtain the desired added-value products [72,75]. Due to the large quantity of existing literature about the biotransformation of terpenes in this study we focus on the bioconversion of terpenes obtained from essential oils (geraniol), agro-foods (limonene), and forestry industrial residues (1,8-cineole and pinenes).

Geraniol is one of the most important terpenes commercialized in the flavor and fragrance industries [76]. The biotransformation of geraniol through SmF using Penicillium digitatum yielded 6-methyl-5-hepten-2-one (sulcatone) (Figure 1) [77]. Sulcatone proved to be an effective insecticide against Spodoptera littoralis, with a strong impact on larval mortality and a reduction in the emergence of adults [78]. In addition, a positive response of Philaenus spumarius L. (Hemiptera) to sulcatone was reported. This insect is a vector of Xylella fastidiosa, a phytopathogenic proteobacterium, that attacks crops such as olive, grape, plum, and lemon, and both can be controlled through the development of new formulations based on sulcatone [79].

The essential oil obtained from the petals of Rosa damascena has great economic value and is highly appreciated as a base material in the fragrance and flavor industries. Its chemical composition is mainly geraniol, nerol, and phenylethyl alcohol. However, the fermentation of the rose petals reduces the content of geraniol while increasing the concentration of citronellol [80]. During grape fermentation by Saccharomyces cerevisiae, geraniol is converted into linalool or nerol or it is reduced into citronellol (Figure 1) [81]. Alcohol acetyltransferase (Atf1p) is the enzyme involved in the esterification process during fermentation, while the old yellow enzyme (Oye2p), a flavoprotein, catalyzes the reduction of geraniol to citronellol [81]. According to Soares-Rodrigues et al. [82] linalyl acetate, neryl acetate, citronellyl acetate, and geranyl acetate are excellent biopesticides compounds against Drosophila melanogaster and Reticulitermes chinensi.

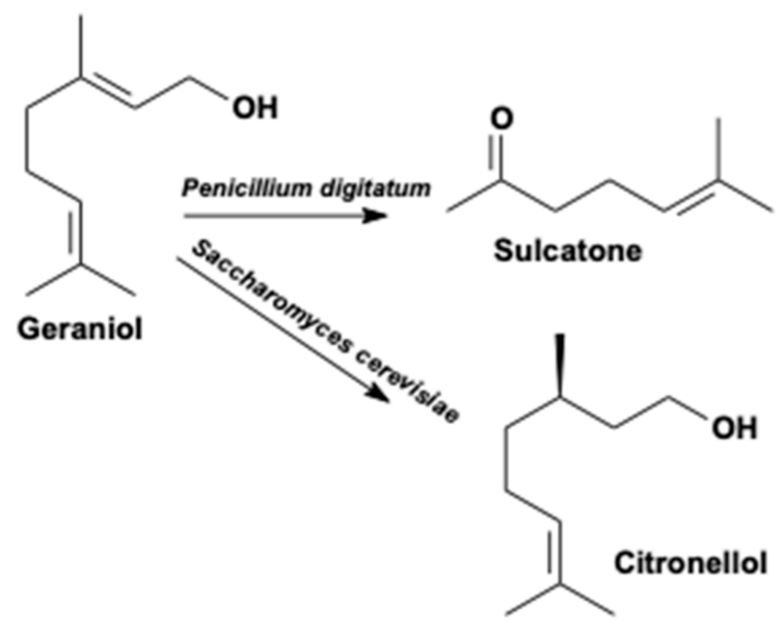

Figure 1. Biotransformation of geraniol into sulcatone and citronellol, two new biopesticide compounds, by Penicillium digitatum and Saccharomyces cerevisiae, respectively $[78,81]$. 
Limonene isomers are the most abundant monoterpene hydrocarbons found in nature. (+)-(R)-limonene is the major constituent of the essential oil obtained from citrus peels [83]. A 50-year literature review shows that the biotransformation of limonene by different types of microorganisms (bacteria, filamentous fungi, and yeasts) produces carveol, carvone, perillyl alcohol, isopiperitenol, $\alpha$-terpineol, and limonene 1,2-diol [83-85] as main components. The biotransformation products of limonene generated by bacteria are mainly perillaldehyde, perillic acid, limonene-1,2-epoxide, and limonene-8,9-epoxide, while isopiperitenone, limonene-4-ol, and cis/trans-mentha-2,8-dienol are commonly generated by filamentous fungi and yeasts. Limonene dioxide, cis-linalool oxide, and limonene-1,2-diol are neurotoxic compounds for insects, affecting them at different stages of their development (Figure 2) [86]. Limonene caused a 70.7\% mortality in Sitophilus granarius adults, whereas the oxygenated compound, limonene oxide, obtained through fermentation resulted in a mortality of $100 \%$ [87]. On the other hand, limonene itself has a broad insecticidal spectrum and is a component of several formulations of commercial products [73]. The production of limonene through fermentation using microorganisms offers an alternative strategy to meet the current requirements for this natural compound [88].

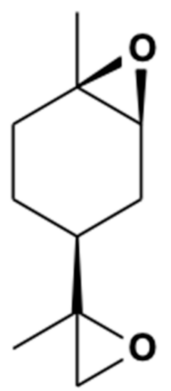

Limonene dioxide

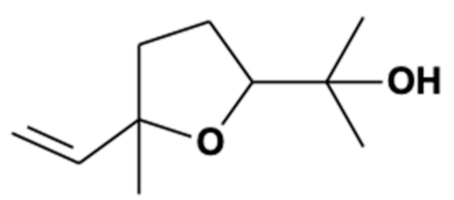

Linalool oxide

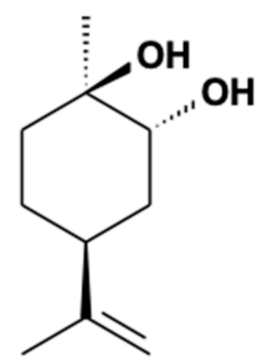

Limonene-1,2-diol

Figure 2. Biotransformation products with insecticidal properties obtained though fermentation of limonene [86].

Fermentation of the epoxylated terpene 1,8-cineole by Pleurotus ostreatus and Favolus tenuiculus produced 1,3,3-trimethyl-2-oxabicyclo [2.2.2] octan-6-ol and 1,3,3- trimethyl-2-oxabicyclo [2.2.2] octan-6-one [14]. Conversion of 1,8-cineole by the bacterium Pseudomona flava produced the same compounds [89]. Fermentation by A. niger produced two alcohols and one ketone, but the oxidation occurred at the C-3 position of the monoterpene [90]. The repellent and insecticidal properties of 1,8-cineole and its derivatives have been widely reported against several insects [73].

Turpentine is an important product obtained mainly from pine trees by the forestry industry. The isomers $\alpha$-pinene and $\beta$-pinene are the main components of turpentine. These pinenes are differentially distributed in some species of Pinus spp. resins [84]. The use of pinene as carbon source to carry out fermentation with different filamentous fungi generated (+)-verbenone, $(+)$-cis-verbenol, pinocarveol, pinocarvone, and hydroxy-pinenes as the main biotransformed products. On the other hand, when the fermentation of pinene is carried out using bacteria species, the main products recovered are camphor, borneol, myrtenol, and myrtenic acid [84]. Under certain culture conditions, the $(+)-(1 R, 2 S, 4 R)-1-p$-menthane-2,8-diol can be obtained from the fermentation of $\alpha$ - or $\beta$-pinene using different strains of $A$. niger. The insecticidal properties of terpenes products have been extensively reported $[82,84,91]$.

\subsection{Phenols}

Phenolic compounds are a diverse group of plant secondary metabolites that can be recovered from agricultural and forestry industrial waste using different downstream processes, and also through microbial degradation of the polymers that constitute the plant cell wall. In plants, phenolics are synthetized through the pentose phosphate, shikimate, and phenylpropanoid pathways, and they can 
be classified based on their carbon skeletons as phenolic acids, flavonoids, stilbenes, tannins, lignans, coumarins, curcuminoids, or quinones [92].

Flavonoids are well-known bioactive compounds with numerous benefits, mostly attributed to their antioxidant activity [93]. Monomers released during the fungal degradation or bioconversion of plant-based materials are generally gallic acid and ellagic acid from hydrolysable tannins, whereas catechin, epicatechin, and gallocatechin derive from condensed tannins. As an advantage, this strategy enhances compounds' bioactivities and readiness [94,95]. Furthermore, this innovative process is in agreement with the European regulation on flavors (EC N8 1334/2008), which indicates that compounds obtained from materials of natural origin (vegetal, animal, or microbiological sources) using physical, enzymatic, or microbiological processes can be labelled as 'natural'.

During fungal bioconversion of flavonoids different reactions can take place such as hydroxylation, dehydroxylation, $\mathrm{O}$-methylation, $\mathrm{O}$-demethylation, glycosylation, deglycosylation, hydrogenation, dehydrogenation, $\mathrm{C}$ ring cleavage of the benzo- $\gamma$-pyrone system, cyclization, and carbonyl reduction (Figure 3) [92,96]. Fungal enzymes such as peroxidases, laccases, tannases, or dioxygenases can be used for the structural transformation of flavonoids (increasing the number of hydroxyl groups). For example, naringenin has been enzymatically converted into carthamidin and isocarthamidin, and these structural changes increased the antioxidant capacity and improved the antimicrobial and larvicide activities, thereby showing the potential for the development of new bioactive formulations to use in the food and agrochemical industry $[21,97,98]$.

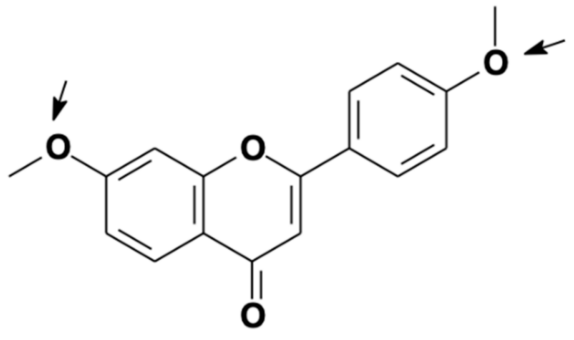

Multimethoxy flavanone

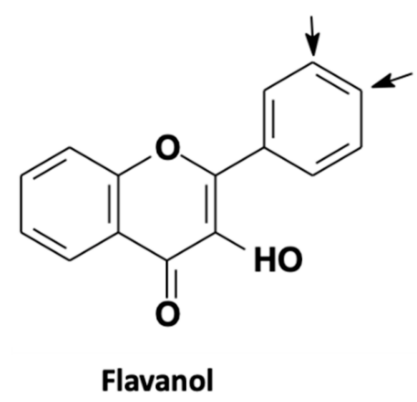

Flavanol

Figure 3. Demethylation sites of multimethoxylated flavanones and methylation sites of flavanols that can be modified by microbial enzymes during fermentation. The arrows indicate the demethylation and methylation sites of each compound [96].

The biotransformation of flavones during fermentation occurs through the hydroxylation on the ortho position of the hydroxyl group on the A ring and C-4' position of the B ring (Figure 4). Flavonols are hydroxylated at C-8 position, while the hydroxylation of flavanones occurs at C-5, C-6 and C- $4^{\prime}$ positions, and the isoflavones are usually hydroxylated at C-3' position of the B ring (Figure 4) [96]. The presence of a hydroxyl groups at C-3 or C-7 positions facilitates glycosylation during this biotransformation [96]. During the bioconversion process, the flavonols are O-methylated at $\mathrm{C}-3^{\prime}$ and $\mathrm{C}-4^{\prime}$ positions, the flavones at C-6 position, while in flavanones this occurs at the hydroxyl groups of the A ring. The conversion of flavonoids into chalcones can also occur through the rupture of the $\mathrm{C}$ ring [96]. The presence of electron-donating groups located at the $\mathrm{A}$ or $\mathrm{B}$ ring of chalcones increases their insecticidal property, especially against mosquito larvae. However, the presence of a methyl group on the A ring drastically reduces this property [99]. On the other hand, it was observed that methoxylation increases the antifeedant activity of flavones [100], as long as they do not occur at C-6 or C-7 positions [101]. The absence of a substituent of flavonoids on the B ring produces antifeedant properties against Spodoptera litura larvae [100,102]. Similarly, Romanelli et al., [101] showed that the insecticidal activity against $S$. frugiperda decreases when the flavone has a methyl, methoxy, or hydroxyl substituents at the C-6 or C-7 position. 

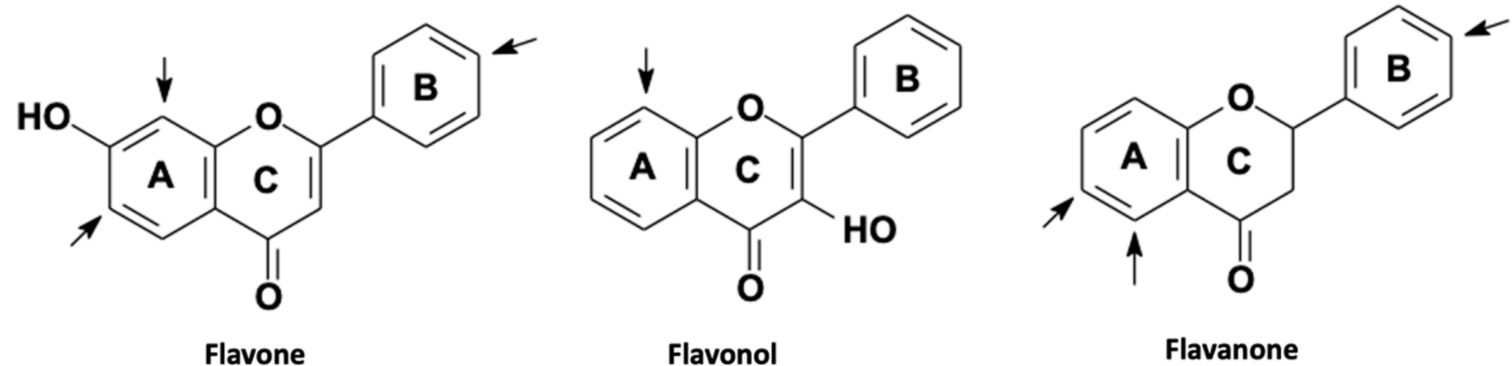

Figure 4. Hydroxylation sites of the main flavonoids compounds that can be modified by microorganisms during fermentation. The arrows indicate the hydroxylation sites in the compounds [97].

Therefore, it is important to highlight the enormous potential offered by phenols bioconversion to increase the availability of natural products or novel compounds, which do not exist in nature and have better bioactivities. The challenge is to work in a multidisciplinary approach in the development of ecofriendly biocatalytic processes for the production of new bio-based compounds with improved biopesticide activities to protect crops from pests, and to demonstrate that it is possible to do it in a more sustainable manner.

\section{Conclusions}

Fermentation is a promising biotechnological approach for the production of useful bioactive products using different plant-based materials. It is also an environmentally-friendly industrial process. During fermentation, bioconversion reactions performed by fungi or their enzymes increase molecular diversity of bioactive metabolites that can be obtained from the substrates. A huge variety of agro-industrial waste or by-products can be easily used as low-cost substrates in fermentation processes and converted into valuable bioactive products such as biopesticides. It is important to mention that the increase in the availability and diversity of natural bioactive compounds will pave the way for the development of new insecticidal formulations. It will allow resistance problems in the control of different pests to be overcome and enable the use of natural bioactive compounds in combination with commercial products so as to achieve synergism and reduce toxicity.

Author Contributions: Conceptualization, review editing, and acquisition of funding A.B.O. and J.A.Z.; investigation, F.A. and V.D.B.; writing—original draft preparation A.B.O., F.A., V.D.B., and J.A.Z.; data curation and formatting of the manuscript F.A. and V.D.B. All authors have read and agreed to the published version of the manuscript.

Funding: This research was partially supported by ERANet-LAC, CPW Biorefinery project (Reference: 3245/2015 (MINCyT), 2017-2020), FONCYT PICT 2016-2496 and PICT 2018-3697 (Argentina), SeCyT-UNC 33620180100129CB (Argentina). CONICET (Argentina) supported A.B.O., J.A.Z., F.A. and V.D.B.

Acknowledgments: We thank to Universidad Nacional de Córdoba, Consejo Nacional de Investigaciones Científicas y Técnicas (CONICET) for their support and Lic. Cecilia Zanucci for English language correction.

Conflicts of Interest: The authors declare no conflict of interest.

\section{References}

1. Hussain, A.; Bose, S.; Wang, J.H.; Yadav, M.K.; Mahajan, G.B.; Kim, H. Fermentation, a feasible strategy for enhancing bioactivity of herbal medicines. Food Res. Int. 2016, 81, 1-16. [CrossRef]

2. Laufenberg, G.; Kunz, B.; Nystroem, M. Transformation of vegetable waste into value added products: (A) the upgrading concept; (B) practical implementations. Bioresour. Technol. 2003, 87, 167-198. [CrossRef]

3. Sadh, P.K.; Duhan, S.; Duhan, J.S. Agro-industrial wastes and their utilization using solid state fermentation: A review. Bioresour. Bioprocess. 2018, 5, 10. [CrossRef]

4. Gupta, A.; Kagliwal, L.D.; Singhal, R.S. Biotransformation of Polyphenols for Improved Bioavailability and Processing Stability. In Advances in Food and Nutrition Research; Taylor, S., Ed.; Academic Press Inc.: Cambridge, MA, USA, 2013; Volume 69, pp. 183-217. 
5. Pandey, A. Solid-state fermentation. Biochem. Eng. J. 2003, 13, 81-84. [CrossRef]

6. Papaspyridi, L.M.; Aligiannis, N.; Topakas, E.; Christakopoulos, P.; Skaltsounis, A.L.; Fokialakis, N. Submerged fermentation of the edible mushroom Pleurotus ostreatus in a batch stirred tank bioreactor as a promising alternative for the effective production of bioactive metabolites. Molecules 2012, 17, 2714-2724. [CrossRef]

7. Zhou, J.; Du, G.; Chen, J. Novel fermentation processes for manufacturing plant natural products. Curr. Opin. Biotechnol. 2014, 25, 17-23. [CrossRef]

8. Arora, S.; Rani, R.; Ghosh, S. Bioreactors in solid state fermentation technology: Design, applications and engineering aspects. J. Biotechnol. 2018, 269, 16-34. [CrossRef]

9. Rodríguez, P.; Cerda, A.; Font, X.; Sánchez, A.; Artola, A. Valorisation of biowaste digestate through solid state fermentation to produce biopesticides from Bacillus thuringiensis. Waste Manag. 2019, 93, 63-71. [CrossRef]

10. Pandey, A.; Soccol, C.R.; Mitchell, D. New developments in solid state fermentation: I-bioprocesses and products. Process Biochem. 2000, 35, 1153-1169. [CrossRef]

11. Postemsky, P.D.; Bidegain, M.A.; Lluberas, G.; Lopretti, M.I.; Bonifacino, S.; Inés Landache, M.; Zygadlo, J.A.; Fernández-Lahore, M.; Omarini, A.B. Biorefining via solid-state fermentation of rice and sunflower by-products employing novel monosporic strains from Pleurotus sapidus. Bioresour. Technol. 2019, 289, 121692. [CrossRef]

12. Omarini, A.; Lechner, B.E.; Albertó, E. Polyporus tenuiculus: A new naturally occurring mushroom that can be industrially cultivated on agricultural waste. J. Ind. Microbiol. Biotechnol. 2009, 36, 635-642. [CrossRef] [PubMed]

13. Omarini, A.B.; Labuckas, D.; Zunino, M.P.; Pizzolitto, R.; Fernández-Lahore, M.; Barrionuevo, D.; Zygadlo, J.A. Upgrading the nutritional value of rice bran by Solid-State fermentation with Pleurotus sapidus. Fermentation 2019, 5, 5-8. [CrossRef]

14. Omarini, A.; Dambolena, J.S.; Lucini, E.; Jaramillo Mejía, S.; Albertó, E.; Zygadlo, J.A. Biotransformation of 1,8-cineole by solid-state fermentation of Eucalyptus waste from the essential oil industry using Pleurotus ostreatus and Favolus tenuiculus. Folia Microbiol. Praha. 2016, 61, 149-157. [CrossRef] [PubMed]

15. Vandenberghe, L.P.S.; Pandey, A.; Carvalho, J.C.; Letti, L.A.J.; Woiciechowski, A.L.; Karp, S.G.; Thomaz-Soccol, V.; Martínez-Burgos, W.J.; Penha, R.O.; Herrmann, L.W.; et al. Solid-state fermentation technology and innovation for the production of agricultural and animal feed bioproducts. Syst. Microbiol. Biomanufac. 2020. [CrossRef]

16. De La Cruz Quiroz, R.; Roussos, S.; Hernández, D.; Rodríguez, R.; Castillo, F.; Aguilar, C.N. Challenges and opportunities of the bio-pesticides production by solid-state fermentation: Filamentous fungi as a model. Crit. Rev. Biotechnol. 2015, 35, 326-333. [CrossRef] [PubMed]

17. Chio, E.H. Insecticides from Fermentation Secondary Metabolites. Formos. Entomol. 2007, 27, 97-106.

18. Matsuda, K. Okaramines and other plant fungal products as new insecticide leads. Curr. Opin. Insect Sci. 2018, 30, 67-72. [CrossRef]

19. Marrone, P.G. The Market and Potential for Molecular POC Diagnostics. In Biopesticides: State of the Art and Future Opportunities; Gross, A.D., Coats, J.R., Duke, S.O., Seiber, J.N., Eds.; ACS Publications: Washington DC, USA, 2014; Volume 9, pp. 245-258.

20. Yoshimoto, J.; Kakutani, T.; Nishida, T. Influence of resource abundance on the structure of the insect community attracted to fermented tree sap. Ecol. Res. 2005, 20, 405-414. [CrossRef]

21. Cha, D.H.; Adams, T.; Werle, C.T.; Sampson, B.J.; Adamczyk, J.J.; Rogg, H.; Landolt, P.J. A four-component synthetic attractant for Drosophila suzukii (Diptera: Drosophilidae) isolated from fermented bait headspace. Pest Manag. Sci. 2014, 70, 324-331. [CrossRef]

22. Kim, G.; Huang, J.H.; McMullen, J.G.; Newell, P.D.; Douglas, A.E. Physiological responses of insects to microbial fermentation products: Insights from the interactions between Drosophila and acetic acid. J. Insect Physiol. 2018, 106, 13-19. [CrossRef]

23. Christiaens, J.F.; Franco, L.M.; Cools, T.L.; de Meester, L.; Michiels, J.; Wenseleers, T.; Hassan, B.A.; Yaksi, E.; Verstrepen, K.J. The fungal aroma gene ATF1 promotes dispersal of yeast cells through insect vectors. Cell Rep. 2014, 9, 425-432. [CrossRef]

24. Davis, T.S.; Crippen, T.L.; Hofstetter, R.W.; Tomberlin, J.K. Microbial Volatile Emissions as Insect Semiochemicals. J. Chem. Ecol. 2013, 39, 840-859. [CrossRef] 
25. Ômura, H.; Honda, K.; Asaoka, K.; Inoue, T.A. Divergent behavioral and electrophysiological taste responses in the mid-legs of adult butterflies, Vanessa indica and Argyreus hyperbius. J. Insect Physiol. 2011, 57, 118-126. [CrossRef]

26. Brown, R.L.; El-Sayed, A.M.; Unelius, C.R.; Suckling, D.M. Attraction of the invasive social wasp, Vespula vulgaris, by volatiles from fermented brown sugar. Entomol. Exp. Appl. 2014, 151, 182-190. [CrossRef]

27. Nigam, P.S. Production of Bioactive Secondary Metabolites. In Biotechnology for Agro-Industrial Residues Utilisation; Nigam, P.S., Pandey, A., Eds.; Springer Nature: Dordrecht, Switzerland, 2009; pp. 129-145.

28. Olukunle, O.F.; Sanusi, A.I. Microbial and Physicochemical Properties of Fermented African Locust Bean (Parkia biglobosa) Effluent and its Biocidal Potential on some Selected Insects. Int. J. Sci. 2018, 7, 49-56. [CrossRef]

29. Nzanza, B.; Mashela, P.W. Control of whiteflies and aphids in tomato (Solanum lycopersicum L.) by fermented plant extracts of neem leaf and wild garlic. Afr. J. Biotechnol. 2012, 11, 16077-16082. [CrossRef]

30. Batish, D.R.; Singh, H.P.; Kohli, R.K.; Kaur, S. Eucalyptus essential oil as a natural pesticide. For. Ecol. Manag. 2008, 256, 2166-2174. [CrossRef]

31. de Ramos, A.S.; Ribeiro, J.B.; Teixeira, B.G.; Ferreira, J.L.P.; de Silva, J.R.A.; do Ferreira, A.A.; de Souza, R.O.M.A.; Amaral, A.C.F. Hydroxylation of 1,8-cineole by Mucor ramannianus and Aspergillus niger. Braz. J. Microbiol. 2015, 46, 261-264. [CrossRef]

32. Pérez-Nájera, V.C.; Lugo-Cervantes, E.; Amaya-Delgado, L.; Madrigal-Pulido, J.A.; Rueda-Puente, E.O.; Borboa-Flores, J.; Del-Toro-Sánchez, C.L. Biotransformation of hesperidin from lime peel (Citrus limetta Risso) in solid fermentation by Aspergillus saitoi. CYTA J. Food 2018, 16, 537-543. [CrossRef]

33. Su, Q.; Zhou, Z.; Zhang, J.; Shi, C.; Zhang, G.; Jin, Z.; Wang, W.; Li, C. Effect of plant secondary metabolites on common cutworm, Spodoptera litura (Lepidoptera: Noctuidae). Entomol. Res. 2018, 48, 18-26. [CrossRef]

34. Sepúlveda, L.; Laredo-Alcalá, E.; Buenrostro-Figueroa, J.J.; Ascacio-Valdés, J.A.; Genisheva, Z.; Aguilar, C.; Teixeira, J. Ellagic acid production using polyphenols from orange peel waste by submerged fermentation. Electron. J. Biotechnol. 2020, 43, 1-7. [CrossRef]

35. Kharat, P.; Sarkar, P.; Mouliganesh, S.; Tiwary, V.; Priya, V.B.R.; Sree, N.Y.; Annapoorna, H.V.; Saikia, D.K.; Mahanta, K.; Thirumurugan, K. Ellagic acid prolongs the lifespan of Drosophila melanogaster. GeroScience 2020, 42, 271-285. [CrossRef] [PubMed]

36. Larios-Cruz, R.; Rodríguez-Jasso, R.M.; Ruiz,H.A.; Prado-Barragán, A.; Wong-Paz, J.E.; Rodríguez-Herrera, R.; Montañez, J.C.; Aguilar, C.N. Utilization of Citrus Waste Biomass for Antioxidant Production by Solid-State Fermentation. In Waste to Wealth, Energy, Environment, and Sustainability; Singhania, R., Agarwal, R., Kumar, R., Sukumaran, R., Eds.; Springer: Singapore, 2018; pp. 83-96.

37. Singh, B.; Kaur, T.; Kaur, S.; Manhas, R.K.; Kaur, A. Insecticidal potential of an endophytic Cladosporium velox against Spodoptera litura mediated through inhibition of alpha glycosidases. Pestic. Biochem. Physiol. 2016, 131, 46-52. [CrossRef]

38. Liu, C.; Hou, W.; Li, S.; Tsao, R. Extraction and isolation of acetylcholinesterase inhibitors from Citrus limon peel using an in vitro method. J. Sep. Sci. 2020, 43, 1531-1543. [CrossRef] [PubMed]

39. Bonomo, M.M.; Fernandes, J.B.; Carlos, R.M.; Fernandes, M.N. Biochemical and genotoxic biomarkers and cell cycle assessment in the zebrafish liver (ZF-L) cell line exposed to the novel metal-insecticide magnesium-hespiridin complex. Chemosphere 2020, 250. [CrossRef] [PubMed]

40. Guo, N.; Zhu, Y.W.; Jiang, Y.W.; Li, H.K.; Liu, Z.M.; Wang, W.; Shan, C.H.; Fu, Y.J. Improvement of flavonoid aglycone and biological activity of mulberry leaves by solid-state fermentation. Ind. Crops Prod. 2020, 148, 112287. [CrossRef]

41. Harwoko, H.; Hartmann, R.; Daletos, G.; Ancheeva, E.; Frank, M.; Liu, Z.; Proksch, P. Biotransformation of Host Plant Flavonoids by the Fungal Endophyte Epicoccum nigrum. ChemistrySelect 2019, 4, 13054-13057. [CrossRef]

42. Ghani, N.A.; Ismail, N.H.; Asakawa, Y. Constituents of fermented male flowers of Alnus sieboldiana (Betulaceae). Nat. Prod. Commun. 2017, 12, 57-58. [CrossRef]

43. Pei, J.; Chen, A.; Dong, P.; Shi, X.; Zhao, L.; Cao, F.; Tang, F. Modulating heterologous pathways and optimizing fermentation conditions for biosynthesis of kaempferol and astragalin from naringenin in Escherichia coli. J. Ind. Microbiol. Biotechnol. 2019, 46, 171-186. [CrossRef]

44. Sharma, R.; Sohal, S.K. Oviposition response of melon fruit fly, Bactrocera cucurbitae (Coquillett) to different phenolic compounds. J. Biopestic. 2016, 9, 46-51. 
45. Ji, Y.; Li, B.; Qiao, M.; Li, J.; Xu, H.; Zhang, L.; Zhang, X. Advances on the in vivo and in vitro glycosylations of flavonoids. Appl. Microbiol. Biotechnol. 2020, 104, 6587-6600. [CrossRef] [PubMed]

46. Queiroz Santos, V.A.; Nascimento, C.G.; Schimidt, C.A.P.; Mantovani, D.; Dekker, R.F.H.; da Cunha, M.A.A. Solid-state fermentation of soybean okara: Isoflavones biotransformation, antioxidant activity and enhancement of nutritional quality. LWT 2018, 92, 509-515. [CrossRef]

47. Dou, F.; Wang, Z.; Li, G.; Dun, B. Microbial transformation of flavonoids by Isaria fumosorosea ACCC 37814. Molecules 2019, 24, 1028. [CrossRef] [PubMed]

48. Makenzi, A.M.; Manguro, L.A.; Owuor, P.O.; Opiyo, S.A. Flavonol glycosides with insecticidal activity from methanol extract of Annona mucosa Jacq. leaves. Trends Phytochem. Res. 2019, 3, 287-296. [CrossRef]

49. Aboshi, T.; Ishiguri, S.; Shiono, Y.; Murayama, T. Flavonoid glycosides in Malabar spinach Basella alba inhibit the growth of Spodoptera litura larvae. Biosci. Biotechnol. Biochem. 2018, 82, 9-14. [CrossRef] [PubMed]

50. Kim, B.G.; Yang, S.M.; Kim, S.Y.; Cha, M.N.; Ahn, J.H. Biosynthesis and production of glycosylated flavonoids in Escherichia coli: Current state and perspectives. Appl. Microbiol. Biotechnol. 2015, 99, 2979-2988. [CrossRef]

51. Pandey, R.P.; Parajuli, P.; Chu, L.L.; Kim, S.Y.; Sohng, J.K. Biosynthesis of a novel fisetin glycoside from engineered Escherichia coli. J. Ind. Eng. Chem. 2016, 43, 13-19. [CrossRef]

52. Muñoz, R.; de las Rivas, B.; López de Felipe, F.; Reverón, I.; Santamaría, L.; Esteban-Torres, M.; Curiel, J.A.; Rodríguez, H.; Landete, J.M. Biotransformation of Phenolics by Lactobacillus plantarum in Fermented Foods. In Fermented Foods in Health and Disease Prevention; Frías, J., Villaluenga, C.M., Peñas, E., Eds.; Elsevier Inc.: Amsterdam, The Netherlands, 2017; pp. 63-83.

53. Chauhan, N.S.; Sohal, S.K. Disruptive effect of pyrogallol on development of Spodoptera litura (Fab.) larvae. J. Biopestic. 2018, 11, 7-13.

54. Abdulla, S.W. Identification of Gallic acid and Hydroquinone in the Propolis and their effects on ovaries of Khapra beetle Trogoderma granarium Everts Coleoptera: Dermestidae 2. Polytechnic 2016, 6, 281-286.

55. Ahmed, A.; Abou-Taleb, K. Implementation of Different Fermentation Techniques for Induction of Tannase and Gallic Acid Using Agro-residues Substrates. Egypt. J. Microbiol. 2019, 54, 39-54. [CrossRef]

56. Abd Razak, D.L.; Abd Rashid, N.Y.; Jamaluddin, A.; Sharifudin, S.A.; Abd Kahar, A.; Long, K. Cosmeceutical potentials and bioactive compounds of rice bran fermented with single and mix culture of Aspergillus oryzae and Rhizopus oryzae. J. Saudi Soc. Agric. Sci. 2017, 16, 127-134. [CrossRef]

57. Yang, J.; Sun, X.Q.; Yan, S.Y.; Pan, W.J.; Zhang, M.X.; Cai, Q.N. Interaction of Ferulic Acid with Glutathione S-Transferase and Carboxylesterase Genes in the Brown Planthopper, Nilaparvata lugens. J. Chem. Ecol. 2017, 43, 693-702. [CrossRef]

58. Pavela, R. Insecticidal properties of phenols on Culex quinquefasciatus Say and Musca domestica L. Parasitol. Res. 2011, 109, 1547-1553. [CrossRef] [PubMed]

59. Tong, S.M.; Feng, M.G. Aphidicidal activity of a novel botanical insecticide made by alkalization of bamboo tar. Crop Prot. 2016, 87, 85-89. [CrossRef]

60. Hagner, M.; Tiilikkala, K.; Lindqvist, I.; Niemelä, K.; Wikberg, H.; Källi, A.; Rasa, K. Performance of Liquids from Slow Pyrolysis and Hydrothermal Carbonization in Plant Protection. Waste Biomass Valorization 2020, 11, 1005-1016. [CrossRef]

61. Pavela, R. Antifeedant and larvicidal effects of some phenolic components of essential oils lasp lines of introduction against Spodoptera littoralis (boisd.). J. Essent. Oil-Bear. Plants 2011, 14, 266-273. [CrossRef]

62. Zhou, Y.; Wang, R.; Zhang, Y.; Yang, Y.; Sun, X.; Zhang, Q.; Yang, N. Biotransformation of phenolics and metabolites and the change in antioxidant activity in kiwifruit induced by Lactobacillus plantarum fermentation. J. Sci. Food Agric. 2020, 100, 3283-3290. [CrossRef]

63. Maazoun, A.M.; Hlel, T.B.; Hamdi, S.H.; Belhadj, F.; Jemâa, J.M.B.; Marzouki, M.N. Screening for insecticidal potential and acetylcholinesterase activity inhibition of Urginea maritima bulbs extract for the control of Sitophilus oryzae (L.). J. Asia. Pac. Entomol. 2017, 20, 752-760. [CrossRef]

64. Fraga, B.M.; González-Coloma, A.; Alegre-Gómez, S.; López-Rodríguez, M.; Amador, L.J.; Díaz, C.E. Bioactive constituents from transformed root cultures of Nepeta teydea. Phytochemistry 2017, 133, 59-68. [CrossRef]

65. Wu, C.; Li, T.; Qi, J.; Jiang, T.; Xu, H.; Lei, H. Effects of lactic acid fermentation-based biotransformation on phenolic profiles, antioxidant capacity and flavor volatiles of apple juice. LWT 2020, 122, 109064. [CrossRef]

66. Stuhl, C.J. Does Prior Feeding Behavior by Previous Generations of the Maize Weevil (Coleoptera: Curculionidae) Determine Future Descendants Feeding Preference and Ovipositional Suitability? Fla. Entomol. Soc. 2019, 102, 366-372. [CrossRef] 
67. Herrera, J.M.; Zunino, M.P.; Dambolena, J.S.; Pizzolitto, R.P.; Gañan, N.A.; Lucini, E.I.; Zygadlo, J.A. Terpene ketones as natural insecticides against Sitophilus zeamais. Ind. Crops Prod. 2015, 70, 435-442. [CrossRef]

68. Brito, V.D.; Achimón, F.; Dambolena, J.S.; Pizzolitto, R.P.; Zygadlo, J.A. Trans-2-hexen-1-ol as a tool for the control of Fusarium verticillioides in stored maize grains. J. Stored Prod. Res. 2019, 82. [CrossRef]

69. Kamauchi, H.; Kon, T.; Kinoshita, K.; Takahashi, K.; Koyama, K. Three new terpenoids, sterebins O, P1, and P2, isolated from Stevia rebaudiana fermented by Saccharomyces cerevisiae. Tetrahedron Lett. 2014, 55, 7203-7205. [CrossRef]

70. Dong, J.W.; Cai, L.; Li, X.J.; Shi, Y.X.; Wang, J.P.; Mei, R.F.; Ding, Z.T. A new menthane-type monoterpenoid from fermented Illigera aromatica with Clonostachys rogersoniana 828H2. J. Asian Nat. Prod. Res. 2019, 21, 673-678. [CrossRef]

71. Kettering, M.; Valdivia, C.; Sterner, O.; Anke, H.; Thines, E. Heptemerones A-G, seven novel diterpenoids from Coprinus heptemerus: Producing organism, fermentation, isolation and biological activities. J. Antibiot. Tokyo 2005, 58, 390-396. [CrossRef]

72. Çorbac1, C. Biotransformation of terpene and terpenoid derivatives by Aspergillus niger NRRL 326. Biol. Bratisl. 2020, 75, 1473-1481. [CrossRef]

73. Tripathi, A.K.; Mishra, S. Plant Monoterpenoids (Prospective Pesticides). In Ecofriendly Pest Management for Food Security; Academic Press: Cambridge, MA, USA, 2016; pp. 507-524.

74. Cloyd, R.A.; Galle, C.L.; Keith, S.R.; Kalscheur, N.A.; Kemp, K.E. Effect of commercially available plant-derived essential oil products on arthropod pests. J. Econ. Entomol. 2009, 102, 1567-1579. [CrossRef]

75. Duetz, W.A.; Bouwmeester, H.; Van Beilen, J.B.; Witholt, B. Biotransformation of limonene by bacteria, fungi, yeasts, and plants. Appl. Microbiol. Biotechnol. 2003, 61, 269-277. [CrossRef]

76. Chen, W.; Viljoen, A.M. Geraniol-A review of a commercially important fragrance material. S. Afr. J. Bot. 2010, 76, 643-651. [CrossRef]

77. Larios-Cruz, R.; Londoño-Hernández, L.; Gómez-García, R.; García-Galindo, I.; Sepulveda, L.; Rodríguez-Herrera, R.; Aguilar, C.N. Extraction of Bioactive Molecules through Fermentation and Enzymatic Assisted Technologies. In High Value Fermentation Products; Saran, S., Babu, V., Chaubey, A., Eds.; Scrivener Publishing LLC: Beverly, MA, USA, 2019; Volume 1, pp. 27-59.

78. Emara, T.E. Effect of 6-methyl-5-hepten-2-one on acetylcholinesterase activity, growth and development of Spodoptera litoralis. Egypt. J. Biol. 2004, 6, 136-146. [CrossRef]

79. Germinara, G.S.; Ganassi, S.; Pistillo, M.O.; Di Domenico, C.; De Cristofaro, A.; Di Palma, A.M. Antennal olfactory responses of adult meadow spittlebug, Philaenus spumarius, to volatile organic compounds (VOCs). PLoS ONE 2017, 12, e0190454. [CrossRef]

80. Baydar, H.; Baydar, N.G. The effects of harvest date, fermentation duration and Tween 20 treatment on essential oil content and composition of industrial oil rose (Rosa damascena Mill.). Ind. Crops Prod. 2005, 21, 251-255. [CrossRef]

81. Steyer, D.; Erny, C.; Claudel, P.; Riveill, G.; Karst, F.; Legras, J.L. Genetic analysis of geraniol metabolism during fermentation. Food Microbiol. 2013, 33, 228-234. [CrossRef]

82. Soares Rodrigues, G.C.; Dos Santos Maia, M.; Muratov, E.N.; Scotti, L.; Scotti, M.T. Quantitative Structure-Activity Relationship Modeling and Docking of Monoterpenes with Insecticidal Activity against Reticulitermes chinensis Snyder and Drosophila melanogaster. J. Agric. Food Chem. 2020, 68, 4687-4698. [CrossRef]

83. Sales, A.; Afonso, L.F.; Americo, J.A.; de Freitas Rebelo, M.; Pastore, G.M.; Bicas, J.L. Monoterpene biotransformation by Colletotrichum species. Biotechnol. Lett. 2018, 40,561-567. [CrossRef]

84. Baser, H.C.; Buchbauer, G. Handbook of Essential Oils. Science, Technology and Applications; CRC Press: Boca Raton, FL, USA, 2010; Volume 72, pp. 1-949.

85. Janocha, S.; Schmitz, D.; Bernhardt, R. Terpene hydroxylation with microbial cytochrome p450 monooxygenases. Adv. Biochem. Eng. Biotechnol. 2015, 148, 215-250. [CrossRef]

86. Coats, J.R.; Karr, L.L.; Drewes, C.D. Toxicity and Neurotoxic Effects of Monoterpenoids. In Insects and Earthworms; Hedin, P., Ed.; ACS Symposium Series: Washington, DC, USA, 1991; pp. 305-316.

87. Kordali, Ş.; Usanmaz, A.; Bayrak, N.; Çakır, A. Fumigation of volatile monoterpenes and aromatic compounds against adults of Sitophilus granarius (L.) (coleoptera: Curculionidae). Rec. Nat. Prod. 2017, 11, 362-373. 
88. Cheng, B.Q.; Wei, L.J.; Lv, Y.B.; Chen, J.; Hua, Q. Elevating Limonene Production in Oleaginous Yeast Yarrowia lipolytica via Genetic Engineering of Limonene Biosynthesis Pathway and Optimization of Medium Composition. Biotechnol. Bioprocess Eng. 2019, 24, 500-506. [CrossRef]

89. Mikami, Y. Microbial conversion of terpenoids. Biotechnol. Genet. Eng. Rev. 1988, 6, 271-320. [CrossRef]

90. Nishimura, H.; Noma, Y.; Mizutan, J. Eucalyptus as biomass. Novel compounds from microbial conversion of 1,8-cineole. Agric. Biol. Chem. 1982, 46, 2601-2604. [CrossRef]

91. Dambolena, J.S.; Zunino, M.P.; Herrera, J.M.; Pizzolitto, R.P.; Areco, V.A.; Zygadlo, J.A. Terpenes: Natural Products for Controlling Insects of Importance to Human Health-A Structure-Activity Relationship Study. Psyche Lond. 2016, 2016. [CrossRef]

92. Mark, R.; Lyu, X.; Lee, J.J.L.; Parra-Saldívar, R.; Chen, W.N. Sustainable production of natural phenolics for functional food applications. J. Funct. Foods 2019, 57, 233-254. [CrossRef]

93. Tripoli, E.; La Guardia, M.; Giammanco, S.; Di Majo, D.; Giammanco, M. Citrus flavonoids: Molecular structure, biological activity and nutritional properties: A review. Food Chem. 2007, 104, 466-479. [CrossRef]

94. Fierascu, R.C.; Fierascu, I.; Avramescu, S.M.; Sieniawska, E. Recovery of natural antioxidants from agro-industrial side streams through advanced extraction techniques. Molecules 2019, 24, 1-29. [CrossRef]

95. Huerta-Ochoa, S.; Castillo-Araiza, C.O.; Guerrero, A.R.; Prado-Barragán, A. Whole-Cell Bioconversion of Citrus Flavonoids to Enhance Their Biological Properties. In Studies in Natural Products Chemistry; Rahman, A., Ed.; Elsevier B.V.: New York, NY, USA, 2018; Volume 61, pp. 335-367.

96. Cao, H.; Chen, X.; Jassbi, A.R.; Xiao, J. Microbial biotransformation of bioactive flavonoids. Biotechnol. Adv. 2015, 33, 214-223. [CrossRef]

97. Karabin, M.; Hudcova, T.; Jelinek, L.; Dostalek, P. Biotransformations and biological activities of hop flavonoids. Biotechnol. Adv. 2014, 33, 1063-1090. [CrossRef]

98. Parshikov, I.A.; Sutherland, J.B. Biotransformation of Steroids and Flavonoids by Cultures of Aspergillus niger. Appl. Biochem. Biotechnol. 2015, 176, 903-923. [CrossRef]

99. Begum, N.A.; Roy, N.; Laskar, R.A.; Roy, K. Mosquito larvicidal studies of some chalcone analogues and their derived products: Structure-activity relationship analysis. Med. Chem. Res. 2011, 20, 184-191. [CrossRef]

100. Morimoto, M.; Komai, K. Insect antifeedant activity of natural products and the structure-activity relationship of their derivatives. In Natural Products for Pest Management; ACS Publishing: Washington, DC, USA, 2006; Volume 927, pp. 182-193. ISBN 0841239339.

101. Romanelli, G.P.; Virla, E.G.; Duchowicz, P.R.; Gaddi, A.L.; Ruiz, D.M.; Bennardi, D.O.; Del Valle Ortiz, E.; Autino, J.C. Sustainable synthesis of flavonoid derivatives, QSAR study and insecticidal activity against the fall armyworm, Spodoptera frugiperda (Lep.: Noctuidae). J. Agric. Food Chem. 2010, 58, 6290-6295. [CrossRef]

102. Duchowicz, P.R.; Goodarzi, M.; Ocsachoque, M.A.; Romanelli, G.P.; del Ortiz, E.V.; Autino, J.C.; Bennardi, D.O.; Ruiz, D.M.; Castro, E.A. QSAR analysis on Spodoptera litura antifeedant activities for flavone derivatives. Sci. Total Environ. 2009, 408, 277-285. [CrossRef]

Publisher's Note: MDPI stays neutral with regard to jurisdictional claims in published maps and institutional affiliations.

(C) 2020 by the authors. Licensee MDPI, Basel, Switzerland. This article is an open access article distributed under the terms and conditions of the Creative Commons Attribution (CC BY) license (http://creativecommons.org/licenses/by/4.0/). 